\title{
DIFFERENTIATION OF SYNCRETIC CATEGORIES, DUAL CATEGORIES AND OTHER APPROXIMATE PHENOMENA IN THE SYNTACTIC LANGUAGE SYSTEM (ON THE MATERIAL OF THE UKRAINIAN LANGUAGE)
}

\section{Kobchenko N. V.}

\section{INTRODUCTION}

The theory of syncretism appeared because language units violating the correlation "one form = one function" attracted attention of a great number of linguists. Contemporary European and American scholars define syncretism as homonymy of morphological forms that have different syntactic functions, as the "mismatching between syntax and morphology"1. Mostly, they conduct studies based on the case systems of inflectional languages ${ }^{2}$, personal pronouns of various languages ${ }^{3}$, tense forms of verbs ${ }^{4}$, or other categories and units ${ }^{5}$. The research of the

${ }^{1}$ Baerman M., Brown D., Corbett G. The Syntax-Morphology Interface: a Study of Syncretism. Cambridge: Cambridge University Press, 2005. P. 2.

2 Meiser G. Syncretism in Indo-European Languages - Motives, Process and Results // Transactions of the philological society. 1992. Vol. 90, iss. 2. Pp. 187-218; Baerman M. Directionality and (Un)Natural Classes in Syncretism // Language. 2004. Vol. 80 (4). Pp. 807-827; Brown D., Tiberius C., Corbett G. Inflectional syncretism and corpora // Paper presented at the 5th International Workshop on Linguistically Interpreted Corpora (LINC-04) held at the 20th International Conference on Computational Linguistics, Geneva, 2004. URL: http://epubs.surrey.ac.uk/1059/; Baerman M., Brown D., Corbett G. The SyntaxMorphology Interface: a Study of Syncretism. Cambridge: Cambridge University Press, 2005. 279 pp.; Feldstein R. F. Russian Stress and the Notion of Syncretism // Balto-slavjanskaja akcentologija. IWoBA VII: (Balto-Slavic Accentology. IWoBA VII) Moscow, 2016.

${ }^{3}$ Sauerland U., Bobaljik J. D. Syncretism Distribution Modelling: Accidental Homophony as A Random Event // Proceedings of GLOW in Asia IX 2012. Tsu, Japan, 2013: University of Mie. Pp. 31-53.

${ }^{4}$ Meiser G. Syncretism in Indo-European Languages - Motives, Process and Results // Transactions of the philological society. 1992. Vol. 90, iss. 2. Pp. 187-218; Aalberse S., Don J. Syncretism in Dutch Dialects // Morphology. 2009. Vol. 19 (1). Pp. 3-14; Bank S. Segmentation: a Remark on the Syncretism Principle // Morphology. 2017. Vol. 27 (1). Pp. 1-20. 
aforesaid subject is not represented in Ukrainian linguistics, despite the potential of the Ukrainian language as an inflectional one. This fact seems to be caused by different approaches to syncretism. In particular, it is common to consider the nominative and the accusative cases of the Ukrainian male inanimate nouns ( $\mathrm{cmin}$ - stil 'table' as nominative and cmiл - stil 'table' as accusative, for example) to be two different forms performing different functions, but with the same phonemic structure, and treat them as so called 'morphological homonyms'. To be precise, morphological homonyms are considered to be two (or more) separate units; at the same time, syncretic phenomenon is a one-language unit which combines particular features of two (sometimes more) units. While studying these issues, Ukrainian scholars focus on the syntactic level and investigate the syntaxemes of syncretic semantic functions ${ }^{6}$, sentences of syncretic structure and/or semantics ${ }^{7}$, syncretic semanticsyntactic relations between clauses within complex sentences ${ }^{8}$, and

${ }^{5}$ Hein J., Murphy A. Case Mismatches and Syncretism in ATB Dependencies // Replicative Processes in Grammar (Linguistische Arbeits Berichte). Leipzig: University of Leipzig, 2016. Pp. 301-350.

${ }^{6}$ Вихованець I.P. Нариси $з$ функціонального синтаксису української мови. К.: Наук. думка, 1992. С. 161-186; Загнітко А.П. Синкретизм у системі синтаксичних форм // Синкретизм и омонимия в грамматических системах славянских языков: [тезисы доклад. Межрегиональной научно-теоретической конференции]. Измаил: Изд-во Измаильского гос. пед. ин-та, 1994. С. 10-11; Кобченко Н. Реалізація адресатності в синтаксемах синкретичної семантики. Лінгвістичні студії. Вип. 22. Донецьк: ДонНУ, 2011. С. 168-173; Межов О.Г. Типологія мінімальних семантико-синтаксичних одиниць: [монографія]. Луцьк: Волин. нац. ун-т ім. Лесі Українки, 2012. С. 344-485.

7 Христіанінова Р.О. Внутрішній синкретизм складнопідрядних речень. Наук. записки Бердянського держ. пед. у-ту. Сер.: Філологічні науки. 2014. Вип. 1. С. 209-219; Шитик Л.В. Синхронна перехідність синтаксичних одиниць в українській літературній мові: [монографія]. Черкаси: Видавець Чабаненко Ю.А., 2014. 474 с.

8 Зарицька В.Г. Синкретичні типи підрядності у системі складного речення: автореф. дис. на здобуття наук. ступеня канд. філол. наук: спец. 10.02.01 “Українська мова". Дніпропетровськ, 2005. 19 с.; Ожоган В. Синтаксис складнопідрядного елементарного речення. Кіровоград: ЛОВ, 2006. 123 с.; Христіанінова Р.О. Внутрішній синкретизм складнопідрядних речень. Наук. записки Бердянського держ. пед. у-ту. Сер.: Філологічні науки. 2014. Вип. 1. С. 209-219; Шитик Л.В. Синхронна перехідність синтаксичних одиниць в українській літературній мові: [монографія]. Черкаси: Видавець Чабаненко Ю.А., 2014. 474 с. 
syncretic parts of the sentence ${ }^{9}$. Linguists also study syncretic phenomena within parts of $\operatorname{speech}^{10}$. In this paper, we do not consider any of these approaches; instead, we make an attempt to clarify how the theory of syncretism is applied to the study of the syntactic system of a language, and describe the main related problems. This analysis does not aim to cover all aspects of syntactic syncretic phenomena in full, but rather study some of them concerning the dual syntactic connection.

When the term 'syncretism' appeared in the Soviet linguistic metalanguage, its designated the phenomenon of neutralization. Probably, it was determined by the L. Hjemslev's ideas ${ }^{11}$, who considered the nature of grammatical syncretism to be similar to the nature of phonemic neutralization. A similar definition is found in Akhmanova's work ${ }^{12}$ : "Syncretism is a functional merger of various form of expression, the neutralization of contradictions (oppositions); the coincidence of definer near different defined units".

The present-day Ukrainian linguistics understands syncretism as token undifferentiating, dissimilar language units merging into one form $^{13}$ or some particular features in one language unit merging at the same time ${ }^{14}$. Some scholars consistently interpret syncretism as equal to homonymy ${ }^{15}$ or consider homonymy as one of the cases of syncretism ${ }^{16}$.

${ }^{9}$ Наливайко Ю.Ю. Синкретизм у системі членів речення: автореф. дис. на здобуття канд. філол. наук: 10.02.01 "Українська мова". Дніпропетровськ, 2007. $20 \mathrm{c}$.

10 Загнітко А.П. Синкретизм у системі синтаксичних форм // Синкретизм и омонимия в грамматических системах славянских языков: [тезисы доклад. Межрегиональной научно-теоретической конференции]. Измаил: Изд-во Измаильского гос. пед. ин-та, 1994. С. 10-11; Данилюк І.Г. Синкретизм у системі частин мови: автореф. дис. на здобуття наук. ступеня канд. філол. наук: спец. 10.02.01 “Українська мова”. Донецьк, 2006. 20 с.

11 Ельмслев Л. Пролегомены к теории языка // Новое в лингвистике. М.: Прогресс; Изд-во иностранной литературы, 1960. Вып. 1. С. 343-349.

12 Ахманова О.С. Словарь лингвистических терминов. М.: Сов. энцикл., 1966. C. 406.

13 Українська мова: Енциклопедія. К.: Вид-во “Укр. енцикл." ім. М.П. Бажана, 2004. С. 584; Данилюк І.Г. Синкретизм у системі частин мови: автореф. дис. на здобуття наук. ступеня канд. філол. наук: спец. 10.02.01 “Українська мова". Донецьк, 2006. С. 4.

14 Селіванова О. Сучасна лінгвістика: термінологічна енциклопедія. Полтава: Довкілля-К, 2006. С. 540.

15 Селіванова О. Сучасна лінгвістика: термінологічна енциклопедія. Полтава: Довкілля-К, 2006. С. 540. 
A. Zahnitko associates syncretism with inter-speech-parts and intercategorical interaction and supports the differentiation of syncretism, transitivity and poly-functionality ${ }^{17}$. The evolution of the syncretism theory has been influenced by Babaytseva's studies. This linguist proved that syncretism is a part of wider language phenomenon - transitivity which exists in two synchronic and diachronic aspects ${ }^{18}$. According to this concept, syncretism is related to the synchronic transitivity of language units, i.e. the functional scope of what appeared due to the interaction of different categorical units, and hence contain the synthesis of particular features of these interacting units. The same approach to functional syncretism is reflected in the latest monographic survey ${ }^{19}$ that deals with structural and semantic peculiarities of complex sentences, the case study of the Ukrainian language.

To save space and time, various definitions of syncretism are not represented in the paper, i.e. those concerning the language system as a whole, and each level in particular. Ukrainian and Russian scholars ${ }^{20}$ have already discussed it. Although there are some slight discrepancies in the explanations of the phenomenon, all of them have common ideas of 'dualism' and 'transitivity', which form conceptual foundation of syncretism. Therefore, it is important to clear up how such concepts as 'syncretism', 'transitivity' and 'dualism' correlate, especially when applied to the research of the syntactic level. As far as the concepts of

16 Данилюк І.Г. Синкретизм у системі частин мови: автореф. дис. на здобуття наук. ступеня канд. філол. наук: спец. 10.02.01 “Українська мова". Донецьк, 2006. С. 6-7.

17 Загнітко А.П. Синкретизм у системі синтаксичних форм // Синкретизм и омонимия в грамматических системах славянских языков: [тезисы доклад. Межрегиональной научно-теоретической конференции]. Измаил: Изд-во Измаильского гос. пед. ин-та, 1994. С. 10-11.

18 Бабайцева В.В. Явления переходности в грамматике русского языка: [монография]. М.: Издательский дом “Дрофа”, 2000. С. 27-38.

${ }^{19}$ Шитик Л.В. Синхронна перехідність синтаксичних одиниць в українській літературній мові: [монографія]. Черкаси: Видавець Чабаненко Ю.А., 2014. $474 \mathrm{c}$.

${ }^{20}$ Шитик Л.В. Синхронна перехідність синтаксичних одиниць в українській літературній мові: [монографія]. Черкаси: Видавець Чабаненко Ю.А., 2014. С. 29-42; Павлюковец М.А. К вопросу о синкретизме в лингвистической теории // Известия Рос. гос. пед. ун-та им. А.И. Герцена. 2008. № 74 (1). C. 383-390; Колесникова Т.В. О понятии синкретизма в языкознании / URL: http://mx.pglu.ru/lib/publications/University_Reading/ 2008/IV/uch_2008_IV_00025.pdf 
'syncretism' and 'transitivity' are concerned, most of linguists consider them synonymous ${ }^{21}$ or partly synonymous ${ }^{22}$, which seems to be justified. On the other hand, the concepts of 'syncretism' and 'dualism' in terms of their correlation has not studied. Therefore, the main purpose of the paper is to explore and explain the difference between these two concepts relating to the syntactic language system, in particular, to prove the difference between the structures of 'true' dual syntactic connection and structures of 'fictitious' dual syntactic connection.

The general methodology of our survey is based on the principles of functional grammar and is predetermined by the direction from function to form. From this point of view, it is important that the analyzed phenomena (dual syntactic connection) are able to make three-member structures (syntactic triples). Syntactic connection is understood as formal expression of semantic relations between language signs of extralinguistic world things. Considering the combined realization of a sentence on the communicative, semantic-syntactic and formalgrammatical levels, the syntactic connection can be defined as mediated by the semantic-syntactic level formal reflection of real connections between real subjects of the environment.

The following methods were applied to conduct the research: constituent analysis, analysis by the terms of dependence, descriptive and partly the inquiry methods for differentiating syntactic triples framed with the dual syntactic connection and syntactic structures containing syncretic semantic-syntactic relations. The methods of contextual analysis and transformational analysis were employed for distinguishing 'true' and 'fictitious' syntactic triples - constructions illustrating the phenomenon of syntactic homonymy. Attracting the context, wider than sentence and making some structural transformations helped to clarify if some sentence component is subordinate to two governing members at the same time, or to one of them.

The actual material of the study includes sentences illustrating the phenomena under analysis (the manifestation of dual syntactic

21 Мигирин В.Н. Очерки по теории процессов переходности в русском языке. Бельцы, 1971. 199 с.; Бабайцева В.В. Явления переходности в грамматике русского языка: [монография]. М.: Издательский дом “Дрофа", 2000. С. 38; Данилюк І.Г. Синкретизм у системі частин мови: автореф. дис. на здобуття наук. ступеня канд. філол. наук: спец. 10.02.01 "Українська мова". Донецьк, 2006. 20 с.

22 Шитик Л.В. Синхронна перехідність синтаксичних одиниць в українській літературній мові: [монографія]. Черкаси: Видавець Чабаненко Ю.А., 2014. С. 59. 
connection, of syncretic syntactic connection, of the syncretic semanticsyntactic relations, and syntactic homonymy). These sentences are picked from the Ukrainian literature using the method of continuous sampling, and collected from the Ukrainian Language Corp (http://www.mova.info/corpus.aspx?11=209).

\section{Differentiation of Syncretic and Dual Grammatical Categories and Units}

The problem of correlation of the concepts of 'syncretism' and 'dualism' is one of the most important and difficult in the field of untypical language categories and units. The analytical review of specialized literature testifies the tendency to equate these two issues in contemporary linguistics. The observation is grounded on the following facts. Firstly, some researchers interpret sentence components, having potential capacity to depend on two others, as subordinate to two syntactic dominants. In other words, they allow for the manifestation of dual syntactic connection in such sentences ${ }^{23}$. Secondly, some linguists define syncretic parts of the sentence on the grounds of their dual syntactic connection ${ }^{24}$. Thirdly, there is no clear differentiation between such cognitive items as 'dual interpretation' and 'dual function, ${ }^{, 25}$. Thus, language units with dual interpretation as well as language units with dual function are within the scope of syncretism.

Analyzing syntagmatic features of syntactic units, real dependence of components should not be confused with potential dependence. To study the phenomenon of dual syntactic connection, relevant are only those structures where the dependence of some component on two others (or their inter-dependence) is found, as illustrated in (1) and (2). However, if in order to identify dependence one of two semantic interpretations are

${ }^{23}$ Валгина Н.С. О двусторонней синтаксической связи в современном русском языке // Рус. яз. в шк. 1972. № 5. С. 99-104; Пастухова Л.С. Расположение в предложении членов с двойной синтаксической связью // Проблемы теории членов предложения. Кишинев, 1973. С. 5-80; Кононенко В.І. Подвійні синтаксичні зв’язки // Укр. мова і літ. в шк. 1975. № 11. С. 31-42; Шитик Л.В. Синхронна перехідність синтаксичних одиниць в українській літературній мові: [монографія]. Черкаси: Видавець Чабаненко Ю.А., 2014. С. 73.

${ }^{24}$ Наливайко Ю.Ю. Синкретизм у системі членів речення: автореф. дис. на здобуття канд. філол. наук: 10.02.01 “Українська мова”. Дніпропетровськ, 2007. С. 9-10.

25 Данилюк І.Г. Синкретизм у системі частин мови: автореф. дис. на здобуття наук. ступеня канд. філол. наук: спец. 10.02.01 "Українська мова". Донецьк, 2006. С. 15. 
required, as illustrated in (3), there is no dual syntactic connection in the structure. See details in Subsection 3.

(1) Льова вертав додому вельми збентежений (Valeryan Pidmohylnyy).

Liova (Leo Nom) vertav (was coming) dodomu velmy zbentezhenyi (confused participle Nom)

'Leo was coming home too confused' $\leftarrow$ Leo was coming home + Leo was too confused at the same time.

(2) Альошину він наказав лишитись (Mykola Dashkiyev).

Alioshynu (Aloshyn Dat) vin (he Nom) nakazav lyshytys

'He commanded Aloshyn to stay' $\leftarrow$ He commanded Aloshyn + Aloshyn had to stay.

(3) Вони допивали джин з сиропом, як до бару прийшли опришки з Мараморошу (Taras Prokhasko).

Vony (they Nom) dopyvaly dzhyn (gin Accus) z syropom (with syrup Instr) yak do baru (to the pub Gen) pryishly opryshky (opryshoks Nom) $z$ Marmaroshu (from Maramorosh Gen).

'They were drinking up gin with syrup when opryshoks from Maramorosh came to the pub' $\leftarrow$ They were drinking up gin with syrup when opryshoks, who had been born in Maramorosh, came to the pub

or 'They were drinking up gin with syrup when opryshoks came to the pub from Maramorosh' $\leftarrow$ They were drinking up gin with syrup when opryshoks, having left Maramorosh, came to the pub.

From this it follows that the principle of differentiation between 'dual interpretation' and 'dual grammatical basis' is that dual interpretation of a category becomes possible because of non-awareness with the communicative aim of the sentence, and once the communicative aim is revealed, it eliminates the dual interpretation. In other words, the dual interpretation is caused by the absence of complete information related to the category or unit. Correspondingly, the dual grammatical character of a category or a unit is its own objective quality, which is accumulation of particular features of two other categories or units.

Certainly, syncretism, or synchronic transitivity, is grounded on the dualism of internal formation of the language category or unit; it is the prerequisite of syncretism's appearance. Nevertheless, the observations of language system elements and the study of their properties showed that these two concepts are not equal. Specific features of two phenomena, combined in the syncretic phenomenon, are mingle with and penetrate into each other, 
and it is impossible to differentiate between them completely. For example, in morphology of such phenomenon can be illustrated with affixoids, because there are no clear criteria for delimitation between their functioning as root morphemes and affixes (suffixes or prefixes) ${ }^{26}$. Typical are stems where such morphemes function as root (4), but the stems of the words where such morphemes are combined with other roots demonstrate the transitional manifestation of stem (5). Saving of denotative meaning does not deprive them of root status, and at the same time, their regular frequency with the same function in the set of words approximates them to wordformation affixes.

(4)любити - liubyty 'to love', полюбити - poliubyty 'to fall in love', розлюбити - rozliubyty 'to cease to love', любов - liubov 'love', любий - liubyi 'dear', любчик - liubchyk 'darling', нелюб - neliub 'unloved', любо - liubo 'lovely', любитель - liubytel 'amateur', любительський-liubytelskyi 'amateurish', etc.

(5) однолюб - odnoliub 'a person who loves only one person during the whole life', самолюб - samoliub 'a person who loves him-or herself', людинолюб - liudynoliub 'a person who loves people', книголюб - knyholiub 'a person who loves books', прачелюб praceliub 'a person who loves working', життелюб - zhyttieliub 'a person who loves life', правдолюб - pravdoliub 'a person who loves truth', волелюб - voleliub 'a person who loves freedom', теплолюб teploliub 'a person who loves warmth', etc.

The syncretic phenomenon in the scope of parts of speech can be exemplified by infinitive as the unit which combines undifferentiated particular features of noun and verb ${ }^{27}$. In the Ukrainian language (as well as in other Slavic), infinitive naturally functions not only as noun (6), (7),

26 Українська мова: Енциклопедія. К.: Вид-во “Укр. енцикл." ім. М.П. Бажана, 2004. С. 38; Шитик Л.В. Синхронна перехідність синтаксичних одиниць в українській літературній мові: [монографія]. Черкаси: Видавець Чабаненко Ю.А., 2014. С. 62.

27 Бабайцева В.В. Явления переходности в грамматике русского языка: [монография]. М.: Издательский дом “Дрофа”, 2000. С. 135; Вихованець І., Городенська К. Теоретична морфологія української мови: [Академ. граматика української мови]. К.: Унів. вид-во "Пульсари", 2004. С. 120; Данилюк І.Г. Синкретизм у системі частин мови: автореф. дис. на здобуття наук. ступеня канд. філол. наук: спец. 10.02.01 “Українська мова”. Донецьк, 2006. 20 с.; Шитик Л.В. Синхронна перехідність синтаксичних одиниць в українській літературній мові: [монографія]. Черкаси: Видавець Чабаненко Ю.А., 2014. С. 67. 
(8), (9) and verb (10), (11), but it also moves to adjective's (12) and adverb's (13) scopes:

(6) Здобути волю - то мій рай (Pavlo Hrabovskyi).

$\underline{Z}$ dobuty voliu (a freedom Accus) - to miy ray (paradise Nom)

'To gain a freedom is my paradise'.

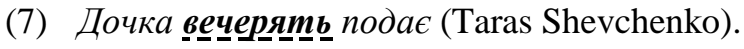

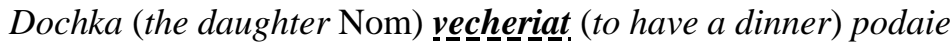

'The daughter is serving the dinner'.

(8) Ані їсти, ані пити (Colloquial).

Ani yisty (to eat) ani pyty (to drink)

'There is no meal, there is no drink'.

(9) Життя прожити - не поле перейти (Folklore).

Zhyttia (a life Accus) prozhyty (to live) ne pole (a field Accus) pereyty

'To live is not to go across a field'.

(10) Вона скінчила писати свою повість (Olha Kobylianska).

Vona (she Nom) skinchyla pysaty svoiu povist (story Accus)

'She finished to write her story'.

(11) [...] вона сміятись та радіми (Marko Vovchok).

[...] vona (she Nom) smiyatys (to laugh) ta radity (to joy)

'...suddenly she started to laugh and to joy'.

(12) В ньому спалахнуло непереможне бажання одразу вмерми (Yuriy Yanovskyi).

$V$ niomu (him Loc) spalakhnulo neperemozhne bazhannia (desire Nom) odrazu vmerty

'The invincible desire to die at once flashed into his mind'.

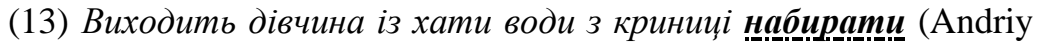
Malyshko).

Vykhodyt divchyna (girl Nom) iz khaty (from the house Gen) vody (water Gen) z krynytsi (from the well Gen) nabyraty.

'The girl goes out to take some water from the well'. 
Among syncretic grammatical categories scholars point out the aspect of Slavic verbs which accumulates derivational and inflectional characteristics $^{28}$, because the formation of aspect pairs corresponds to the both proceeds. Although nowadays linguists insist on distinguishing between derivational and inflectional scopes in the structure of this category, there are aspect pairs that illustrate perfectivation in the derivational space and there are aspect pairs that illustrate imperfectivation in the inflectional space ${ }^{29}$.

As for the syntactic level, undifferentiated dualism is represented by syncretic semantic-syntactic relations that can be actualized between two components of a simple sentence (14), between predicative center and determinant adverbial adjunct (15), or between clauses of complex sentences (16).

(14) Надзвичайно поширювали паніку чутки про самогубство багатьох стариин з їхньої дивізї (Ivan Bahryanyi).

Nadzvychayno poshyriuvaly paniku (panic Accus) chutky (rumors Nom) pro samohubstvo (about suicide Accus) bahatiokh starshyn (petty-officers Gen) z yikhnioyi dyviziyi (of their division Gen)

'The rumors (what rumors? and rumors about what?) about suicide of the majority of petty-officers of their division spread panic extremely'.

(15) Він ставав навколішки й придивлявся, як хиляться сухі стеблини під легким вітром (Yuriy Yanovskyi).

Vin stavav navkolishky i prydyvliavsia yak khyliatsia sukhi steblyny (stalks Nom) pid lehkym vitrom (wind Instr)

'He was standing on knees and watching how dry stalks were sloping under the light wind'. - Why were dry stalks sloping? and Under what circumstances were dry stalks sloping?

28 Jászay L. K характеристике вида и проблеме его определения. Studia Slavica Academiae Scientiarum Hungaricae. 2003. 48. 1-3. Рр. 132; Шитик Л.В. Синхронна перехідність синтаксичних одиниць в українській літературній мові: [монографія]. Черкаси: Видавець Чабаненко Ю.А., 2014. С. 62.

29 Теория функциональной грамматики: введение, аспектуальность, временная локализованность, таксис / отв. ред. А.В. Бондарко. 3-е изд., стереот. М.: УРСС, 2003. С. 84; Вихованець І., Городенська К. Теоретична морфологія української мови: [Академ. граматика української мови]. К.: Унів. вид-во "Пульсари", 2004. С. 225-226. 
(16) Коли в людини є народ, тоді уже вона людина (Lina Kostenko).

Koly v liudyny (a human Gen) ye narod (nation Nom) todi uzhe vona liudyna

'When a person has nation, then he or she is a human'. - When a human is the human? and What circumstances a human is the human in?

At the same time, a language system has phenomena combining these two specific features of other categories of units that can be distinguished simply. As opposed to words containing affixoids, words containing tworoot morphemes, not capable of forming lexemes of the same pattern (17), exemplify dualism with clear delimitation between merging components.

(17) чорнослив - chornoslyv 'prunes' (literary 'black plum'), лісостеn - lisostep 'forest-steppe', кисло-солодкий - kyslo-solodkyi 'sour-sweet', мовностильовий - movnostyliovyi 'lingual-stylistic', часто-густо - chasto-husto 'very frequently' (literary 'frequentlydensely').

There are grounds to consider the grammatical category of case as the category with dual nature, because it is related both to morphological and syntactic levels. However, these two scopes are clearly distinguished in the category: the morphological part of it consists of designing grammemes with flexions, and the syntactic part consists of making up a sentence through filling valent positions of predicate. Besides, classification-inflection grammatical category of number is the category of dual essence which has clear delimitation between merging particularities. The expressional diapasons of its classification and inflection elements are distinguished: all nouns of counted semantic have two morphological forms - singular and plural (inflection element) (18) and all nouns of uncounted semantic are divided into two groups singulative (19) and plurative (20) (classification element).

(18) карта - karta 'a map' - карти - karty 'maps', студент student 'a student' - студенти - studenty 'students', лекиія - lektsiya 'a lecture' - лекиіï-lektsiya 'lecture', nmax - ptakh 'a bird' - nmaxu 'birds'.

(19) padicmь - radist 'gladness', листя - lystia 'leafs', молодь molod 'youth', мед - med 'honey', сміх - smikh 'laugh', волосся volossia 'hair'. 
(20) штани - shtany 'trousers', дверi - dveri 'a door', шахи shakhy 'chess', парфуми - parfumy 'perfume', фінанси - finansy 'finance', гуcu-husy 'geese'.

One of the illustrations of dualistic phenomena with clear delimitation between merging elements on the syntactic level is the complex sentences that contain attributive clause and conjunctional word якийyakyi 'which/ what'. The conjunctional word який (yakyi) (21) is subordinated to two governing members at the same time, but the methods of subordination are different: the word agrees in gender and number with the governing noun in the main clause (реальність realnist 'reality' - singular, female $\Rightarrow$ яка - yaka 'which/ what'singular, female), but its case form is determined by the main verb of the subordinate clause (створила - stvoryla 'created' requires accusative => $я \kappa y-y a k u$ - accusative).

(21) Я живу в реальності, яку створила моя уява (Halyna Pahutyak).

Ya zhyvu $v$ realnosti (in the reality Loc) yaku (which Accus fem) stvoryla moya uyava (imagination Nom)

'I live in the reality which my imagination has created'.

Dual syntactic connection is also actualized in the sentences with socalled predicative attribute or depictive predicates (22). In such constructions, the noun-subject is in interdependent ${ }^{30}$ predicative syntactic connection with the both components of predicate - verb and adjective; at the same time, they are connected with each other through nexus ${ }^{31}$.

(22) Я йшов веселий з нашої таємної пригоди (V. Domontovych).

30 The Ukrainian language is inflectional, so syntactic connection between the nominative as subject and predicate cannot be determined as government, because subject influences the formal expression of predicate as well. There is common term 'coordination' (Shvedova 1971; Vykhovanets 1993, 24). Vykhovanets (1993, 34) interpreted as a synthesis of two syntactic connections - government and agreement: predicate with its valency predetermines the subject in nominative (it is government) case but it also agrees with the subject in number and person, or number and gender (it is agreement).

31 Кобченко Н. Тяжіння: проблема дефініції // Науковий вісник Херсон. держ. ун-ту. Сер. “Лінгвістика”. Вип. 25. Херсон, 2016. С. 9-15. 
Ya ishov veselyi (cheerful Nom) z nashoyi taiemnoyi pryhody (from our Gen secret Gen affair Gen)

'I was walking cheerful from our secret affair' $\leftarrow I$ was walking from our secret affair + I was cheerful at the same time.

From this it follows that it is necessary to differentiate between the phenomena of clear dualism (that contain distinct features of two phenomena) and the phenomena of implicit dualism (that contain mixed features of two phenomena). Evidently, it is disputable to use the term 'proper-dualism' for defining the items of the first type; correspondingly, the items of the second type can be determined as 'diffuse-dualism'. As for the categories and units of proper-dualism, it seems incorrect to qualify them as syncretic or transitional, because at the synchronic stage there is no movement between their components; vice versa, the delimitation between functional domains of these components is clearly distinguished. Oppositely, as far as the phenomena of diffuse-dualism are concerned, these definitions (syncretic or transitional) are quite suitable, because it is impossible to draw a line between their components taking into account their continuous interaction and interpenetration into each other. So, the term 'diffuse-dualism' is a synonym for the terms 'syncretism' and 'transitivity'.

The classical experiment used in physics to show the density of liquid may help to understand the difference between proper-dualism and diffuse-dualism. If you mix water and oil in one glass, at the beginning, some oil particles run to water area, and some water particles run to oil area; then all of the water falls down, and all of the oil goes up under the water; as a result, the clear boundary line appears between them. The process of mixing the liquids, with water particles moving down and oil parts moving up, is similar to the language syncretism (synchronic transitivity or diffuse-dualism) because of absence of delimitation between specific features of two elements in the third element. The final phase of oil's siting above water with a clear borderline between them resembles proper-dualism because of distinguished particularity features of two elements in the third element.

Applying this principle to study syntactic categories, one should focus on differentiating the dual syntactic connection and syncretic, or transitional, connection. Specifically, the dual syntactic connection is not syncretic type of two others, but is a complex connection, which combines two distinguished types of syntactic connections or two distinguished forms of the same type of syntactic connection. It is 
expressed in three-member structures - syntactic triples - and is based on one component depending on two others at the same time (23), or on its inter-depending with the two others at the same time (24).

(23) То була ї̈ ганьба, яку мусила заплатити за порятунок Василька (Volodymyr Lys).

To bula (was fem) yiyi hanba (shame Nom fem), yaku (which Accus fem) musyla zaplatyty za poriatunok (for saving Accus) Vasylka (Vasylko Gen)

'It was her shame which she had to pay for Vasylko's saving'.

(24) Андрюша похмурий сидить у кутку (Mykola Khvylovyi).

Andriusha (Andrusha Nom) pokhmuryi (dreary Nom) sydyt u kutku (in the corner Loc)

'Andrusha is sitting dreary in the corner'.

The syncretic syntactic connection is related to its transitional character compared with the two others. Some syncretic manifestations of syntactic connection have been described in the latest linguistic studies. Namely, grammatical features of syncretic paratactic-hypotactic connection were identified, and their actualization on the level of complex sentence was analyzed ${ }^{32}$. Nonetheless, the case study let us single out another type of syncretic syntactic connection, i.e. the transition between unitary and dual connections. It may be realized in the syntactic triples where one of the components shows the symptoms of grammaticalization or loss of syntactic relations with the other component of this triple due to the change of communicative purpose or semantic upheaval in its internal structure. For example, there is a dual syntactic connection in (25) between the subject and both components of the dual predicate (main and depictive predicates, according to the analysis on the semantic-syntactic level). The verb xодumu - khodyty (to walk) in this sentence is auto-semantical; it even predetermines locative substantive syntaxeme по кімнаті - ро kimnati (in the room) by its

${ }^{32}$ Городенська К. Сполучники української літературної мови: [монографія]. К., Ін-т укр. мови: Видавничий дім Дмитра Бураго, 2010. С. 39-42; Христіанінова Р.О. Складнопідрядні речення в сучасній українській літературній мові: [монографія]. К.: Інститут української мови; Видавничий дім Дмитра Бураго, 2012. с. 285-289; Шитик Л.В. Синхронна перехідність синтаксичних одиниць в українській літературній мові: [монографія]. Черкаси: Видавець Чабаненко Ю.А., 2014. с. 258-263. 
valency. However, in (26), the absence of locative adjuncts and presence of a temporal one with the meaning of a long-term period eliminate the seme 'move' in this verb, and it gets the general meaning of existence. Because of the loss of its semantic and individual syntactic function, the verb is converting to copula, which cannot function as a full member of syntactic connection; instead, it is one of the tools of providing the predicative syntactic connection between the subject and the predicate. So, this verb is losing its capacity to actualize syntactic connection, which makes it possible to determine the syntactic connection in the construction Він ходив простоволосий - Vin khodyv prostovolosyi as transitional between the unitary and dual ones.

(25) Петренко ходив по кімнаті похмурий (Mykola Dashkiyev) $\leftarrow$ Петренко ходив по кімнаті + Петренко був похмурий

Petrenko (Petrenko Nom) khodyv po kimnati (in the room Loc) pokhmuryi (dreary Nom) $\leftarrow$ Petrenko khodyv po kimnati + Petrenko buv pokhmuryi

'Petrenko was walking dreary in the room' $\leftarrow$ Petrenko was walking in the room + Petrenko was dreary at the same time.

(26) Влітку він ходив завжди простоволосий... (Anatoliy Dimarov) = Влітку він був завжди простоволосий.

Vlitku vin khodyv (went) zavzhdy prostovolosyi (bare-headed Nom) = Vlitku vin buv (was) zavzhdy prostovolosyi (bare-headed Nom)

'He was always bare-headed in summer'.

(27) Влітку він ходив завжди простоволосий на пляж $\leftarrow$ Влітку він ходив на пляж + Він був простоволосий

Vlitku vin khodyv zavzhdy prostovolosyi (bare-headed Nom) na pliazh (to the beach Accus) $\leftarrow$ Vlitku vin khodyv na pliazh (to the beach Accus) + Vin buv prostovolosyi (bare-headed Nom)

'He went to the beach bare-headed in summer' $\leftarrow$ He went to the beach in summer + He was bare-headed at the same time.

Analyzing syntactic connections to interpret the above-mentioned concepts, is in conformity with the contemporary theory of syncretism and does not contradict its assumptions. Firstly, syncretism is 
indivisibility, which is normal for the initial stage of evolution ${ }^{33}$. However, sentences with dual syntactic connection do not represent the initial stage of interaction of two basic constructions; oppositely, they are the result of derivational process, in other words, the final stage of the reconstruction of basic syntactic connections and semantic-syntactic relations. Secondly, syncretism allows for unifying two functions in one form $^{34}$. However, dual syntactic connection is actualized in threemember structures, where each component is connected with two others at the same time, and relates to three forms. For example, in (25), dual syntactic connection is objectified in three forms: coordination between Петренко - Petrenko and ходив - khodyv, coordination between Петренко - Petrenko and похмурий - pokhmuryi, and nexus between ходив - khodyv and nохмурий - pokhmuryi (see in ${ }^{35}$ ). Thirdly, in the case of syncretism, there are some factors that can influence the actualization of one of the functions ${ }^{36}$. Dual syntactic connection is realized in structures of a certain patterns by particular forms in a regular way. In its turn, syncretic unitary-dual syntactic connection tends to dominate with one or another feature depending on the presence/absence of components, which influences grammaticalization of one of the

33 Мигирин В.Н. Очерки по теории процессов переходности в русском языке. Бельцы, 1971. С. 99-100; Бабайцева В.В. Явления переходности в грамматике русского языка: [монография]. М.: Издательский дом “Дрофа”, 2000. с. 60; Шитик Л.В. Синхронна перехідність синтаксичних одиниць в українській літературній мові: [монографія]. Черкаси: Видавець Чабаненко Ю.А., 2014. С. 36.

34 Українська мова: Енциклопедія. К.: Вид-во “Укр. енцикл." ім. М.П. Бажана, 2004. С. 584; Селіванова О. Сучасна лінгвістика: термінологічна енциклопедія. Полтава: Довкілля-К, 2006. С. 540; Бабайцева В.В. Явления переходности в грамматике русского языка: [монография]. М.: Издательский дом “Дрофа”, 2000. 640 с.; Загнітко А.П. Синкретизм, поліфункціональність і перехідність морфологічних одиниць // Синкретизм и омонимия в грамматических системах славянских языков: [тезисы доклад. Межрегиональной научно-теоретической конференции]. Измаил: Изд-во Измаильского гос. пед. ин-та, 1994. С. 12-13; Данилюк І.Г. Синкретизм у системі частин мови: автореф. дис. на здобуття наук. ступеня канд. філол. наук: спец. 10.02.01 “Українська мова”. Донецьк, 2006. 20 с.; Шитик Л.В. Синхронна перехідність синтаксичних одиниць в українській літературній мові: [монографія]. Черкаси: Видавець Чабаненко Ю.А., 2014. 474 с.

35 Кобченко Н. Тяжіння: проблема дефініції // Науковий вісник Херсон. держ. ун-ту. Сер. “Лінгвістика”. Вип. 25. Херсон, 2016. С. 9-15.

36 Бабайцева В.В. Явления переходности в грамматике русского языка: [монография]. М.: Издательский дом “Дрофа”, 2000. с. 472. 
components. For example, if in (26) there was no temporal adjunct завжди - zavzhdy, but there was a locative adjunct на пляж - na pliazh, the syntactic connection in the predicative center would be dual (compare with (27)). Ultimately, the fact of existence of syncretic domain between the unitary and dual syntactic connections proves that the latter is not the transitional manifestation of two oppositions, being one of the oppositions itself.

\section{Differentiation of Syncretism and Syntactic Homonymy}

We do not pretend to solve a general linguistic problem of the correlation of syncretism and syntactic homonymy; we just attempt to point out the necessity to differentiate between them to conduct a proper study of the syntactic language system. Moreover, in morphology an approach is found which is partly similar to this one. U. Sauerland and $\mathrm{J}_{\text {. Bobaljik }}{ }^{37}$ have argued that there exists a distinction between accidental homophony and systematic syncretism and suggest applying statistical methods to solve this problem.

First of all, this differentiation is based on the ground of the ways of their expression. Homonymy is in syntax is found when two individual syntactic units with distinct functions have the same form. Whereas syncretism is when a single syntactic unit combines functions of two different units in undifferentiated way. Syncretism of a syntactic unit is determined by its structure and grammatical features of its components and does not depend on the context or communicative purpose. In other words, syncretic syntactic unit is transitional in any context, as in (14), (15), and (16). However, the domain of homonymy is limited by a single sentence and depends on two factors (according to V. Kononenko ${ }^{38}$ ): 1) the capacity of components to express some meaning; 2) sentence structure, where one of the components accepts syntactic connection with different governing members and may frame unequal combinations. Referring to a wider context or finding out the communicative aim eliminates the homonymy, as in (3), (28), and (29). In the first case, the meaning of doubtful components becomes clear. In the second case, the choice of governing member for it becomes apparent.

${ }^{37}$ Sauerland U., Bobaljik J. D. Syncretism Distribution Modelling: Accidental Homophony as A Random Event // Proceedings of GLOW in Asia IX 2012. Tsu, Japan, 2013: University of Mie. Pp. 31-53. URL: http://ling.auf.net/lingbuzz/001718

${ }^{38}$ Кононенко В.I. Омоніміка синтаксичних конструкцій // В.I. Кононенко. Мова. Культура. Стиль: [зб. статей]. К. - Івано-Франківськ: Плай, 2002. C. $120-122$. 


\section{Differentiation of Syntactic Homonyms and Word-Combination with Dual Syntactic Connection}

The confusion of syntactic homonymy and syncretism causes the confusion of the 'true' and 'fictitious' dual syntactic connections (definitions 'true' and 'fictitious' are suggested by V. Kononenko ${ }^{39}$ ). For example, some linguists interpret sentences with the component which has the potential capacity to be subordinated to two governing members - verb and noun - as a domain of dual syntactic connection ${ }^{40}$, see in (28) and (29). It is possible because of the free word-order in Ukrainian (in Russian as well). In particular, N. Valgina ${ }^{41}$ explains that the dual syntactic connection is determined by the decay of verb construction, hence is the syntactic removal of the prepositional noun phrase. Such prepositional noun phrases depend on another noun or occupy the position of a component that determines the whole sentence. The same idea is reflected in the Encyclopedia of Ukrainian language, where so-called dual syntactic connection of prepositional noun phrases in the above-mentioned sentences is declared to be the origin of syncretism on the syntactic level ${ }^{42}$.

(28) Стали вертатись поранені з Павлівки (Yuriy Yanovskyi).

Staly vertatus poraneni (injured men Nom) z Pavlivky (from Pavlivka Gen)

'The injured men from Pavlivka began to come back'.

or 'The injured men began to come back from Pavlivka'.

(29) Що казав цей чоловік людям на березі ставка? (Volodymyr Vynnychenko)

Shcho (what Accus) kazav tsey cholovik (man Nom) liudiam (people Dat) na berezi (on the bank Loc) stavka (lake Gen)?

'What did this man tell to people that stood on the bank of the lake?'

or 'What did this man tell to people on the bank of the lake?'

${ }^{39}$ Кононенко В.І. Подвійні синтаксичні зв'язки // Укр. мова і літ. в шк. 1975. № 11. С. 31-42.

40 Валгина Н.С. О двусторонней синтаксической связи в современном русском языке // Рус. яз. в шк. 1972. № 5. С. 99-104; Пастухова Л.С. Расположение в предложении членов с двойной синтаксической связью // Проблемы теории членов предложения. Кишинев, 1973. С. 5-80.

41 Валгина Н.С. О двусторонней синтаксической связи в современном русском языке // Рус. яз. в шк. 1972. № 5. С. 100-101.

42 Українська мова: Енциклопедія. К.: Вид-во “Укр. енцикл." ім. М.П. Бажана, 2004. С. 584. 
There is also an alternative approach to such structures which implies they do not illustrate the syntactic homonymy but contain the polysemic parts of the sentence. V. Fedosov ${ }^{43}$ suggests the polysemic part of the sentence is a component which has one meaning referring to one sentence part and another meaning referring to another. He also stresses the differences between syncretism and polysemic sentence part, in particular as follows: "Polysemy 'occurs' between different parts of a sentence, though it is the same word phonetically, but syncretism 'occurs' inside a single component, between its form and its meaning",44.

In our opinion, such units are semantically uncertain only within a single sentence, but within a wider context or an external situation, their function is obvious, because their government component is identified. Consequently, there are no positive grounds to qualify such prepositional noun phrases as dependent on two syntactic dominants at the same time. Therefore, we share Chesnokova's opinion ${ }^{45}$, who sticks to the idea of describing such structures as a phenomenon of syntactic homonymy. In addition, Norman's conclusion is disputable because his conclusions are based on the results of the linguistic experiment: "[...] in my opinion, in the aforesaid cases, it would be reasonable not to speak about a dual syntactic connection of some word, but about the possibility of dual syntactic analysis of the sentence - the possibility which becomes completely singled one for real reader or listener" ${ }^{, 46}$.

These two opinions are acceptable for us because they confirm that in the analyzed cases, a dependent component can be subordinate to two syntactic dominants only potentially, but in every specific context, it actualizes merely one of its potential dependences.

\section{CONCLUSIONS}

Syncretism as a scientific concept is grounded on two items among others, i.e. transitivity and dualism. Since the theory of synchronic and diachronic transitivity has been argued, the first of them is related to

43 Федосов В.А. Основные понятия русского традиционного синтаксиса в отношении к лексическому составу предложения // Studia Slavica Academiae Scientiarum Hungaricae. 2006. Vol. 51, iss. 3-4. P. 403.

44 Федосов В.А. Основные понятия русского традиционного синтаксиса в отношении к лексическому составу предложения // Studia Slavica Academiae Scientiarum Hungaricae. 2006. Vol. 51, iss. 3-4. P. 404.

45 Чеснокова Л.Д. Связи слов в современном русском языке: [пособ. для учителей]. М.: Просвещение, 1980. С. 69.

${ }^{46}$ Норман Б.Ю. К вопросу о двусторонней синтаксической связи // Рус. яз. в шк. 1980. № 4. С. 86. 
syncretism; therefore, syncretism is to be considered to be a sort of the general issue of transitivity, in particular synchronic transitivity.

Speaking of dualism, the analysis of the nature of different grammatical categories and units proves the necessity of demarcation of proper-dualism, which contains distinct features of the two other phenomena, and diffuse-dualism, which contains mixed features of the two other phenomena. The phenomenon of proper-dualism cannot be qualified as syncretic as long as they contain no mixture or movement between their components; the boundaries between functions of these components are clearly distinguished. Whereas diffuse-dualism expands on language categories and units characterized with merging, interpenetration between their components occurs. Therefore, diffusedualism is completely related to syncretism and synchronic transitivity.

The dual syntactic connection (in the languages of inflexional type, as Ukrainian, for example) is an interesting object of research. This type of syntactic connection is actualized in three-member structures and implies that one of the three components is in relation of dependence or interdependence with the two others at the same time, and these two components are also syntactically connected with each other. There are no grounds to qualify the dual syntactic connection as a syncretic phenomenon because it has all features of proper-dualism. In particular, the component of dual syntactic connection is subordinated to each of the two head elements by different means, or it might have a position of its own in the valency frames of each of the two components.

It is important to differentiate between syncretism and homonymy as syntactic units. Syncretism of a syntactic unit is the result of its structure and/ or grammatical feature of its components, and is obvious in any context, whereas syntactic homonymy is mostly determined by sentence structure in which one of the components has potential to be subordinate to two different governing members and to actualize different semanticsyntactic relations depending on the context. The context being understood, it reduces syntactic homonymy but does not eliminate syncretic semantics of the structure. Furthermore, it is important to differentiate between syntactic homonyms and structures with dual syntactic connection. Discordance of this postulate provokes the 'fictitious' dual syntactic connection, which is illusion qualification of syntactic homonyms. Dual syntactic connection of some component is its real dependence or interdependence on the other two at the same time. On the other hand, in the structures that illustrate syntactic homonymy, the dependence of some component on the other two is potential, and only one subordination is actualized in every specific context. 


\section{SUMMARY}

The research of studies devoted to the problem of syncretism in grammar revealed that this concept comprises a number of phenomena which may differ. The paper deals with clarifying some main problems of investigation of dual syntactic connection and related phenomena of the syntactic level of the language system. The phenomena in questions are regarded as syncretic semantic-syntactic relations and syntactic homonyms. The concepts of 'dualism' and 'transitivity' being the fundamental grounds of syncretism, the relation between them were traced in the study. The paper suggests there are two types of dualism, in particular clear dualism, which does not cause syncretism, and implicit dualism, which is the basis of syncretism. According to this division, it proved the demarcation of dual essence and of syncretic essence in syntax. Moreover, the difference between the structures with dual syntactic connection and those with syntactic homonymy was identified. These findings illustrate a new approach to interpreting syncretism on the grammatical level, which made it possible to develop the theory of the syntactic connections as fundamental categories for the sentence structure.

\section{REFERENCES}

1. Ахманова О.С. Словарь лингвистических терминов. М.: Сов. энцикл., 1966. $608 \mathrm{c.}$

2. Бабайцева В.В. Явления переходности в грамматике русского языка: [монография]. М.: Издательский дом “Дрофа”, 2000. 640 с.

3. Валгина Н.С. О двусторонней синтаксической связи в современном русском языке // Рус. яз. в шк. 1972. № 5. С. 99-104.

4. Вихованець І.Р. Нариси 3 функціонального синтаксису української мови. - К.: Наук. думка, 1992. 224 с.

5. Вихованець I.P. Граматика української мови. Синтаксис: [підручник]. - К.: Либідь, 1993. 368 с.

6. Вихованець I., Городенська К. Теоретична морфологія української мови: [Академ. граматика укр. мови]. К.: Унів. вид-во "Пульсари", 2004. 400 с.

7. Городенська К. Сполучники української літературної мови: [монографія]. К., Ін-т укр. мови: Видавничий дім Дмитра Бураго, 2010. 208 c.

8. Данилюк І.Г. Синкретизм у системі частин мови: автореф. дис. на здобуття наук. ступеня канд. філол. наук: спец. 10.02.01 "Українська мова". Донецьк, 2006. 20 с. 
9. Ельмслев Л. Пролегомены к теории языка // Новое в лингвистике. М.: Прогресс; Изд-во иностранной литературы, 1960. Вып. 1. С. 264-389.

10.Загнітко А.П. Синкретизм, поліфункціональність і перехідність морфологічних одиниць // Синкретизм и омонимия в грамматических системах славянских языков: [тезисы доклад. Межрегиональной научно-теоретической конференции]. Измаил: Изд-во Измаильского гос. пед. ин-та, 1994. С. 12-13.

11.Загнітко А.П. Синкретизм у системі синтаксичних форм // Синкретизм и омонимия в грамматических системах славянских языков: [тезисы доклад. Межрегиональной научно-теоретической конференции]. Измаил: Изд-во Измаильского гос. пед. ин-та, 1994. C. 10-11.

12.Зарицька В.Г. Синкретичні типи підрядності у системі складного речення: автореф. дис. на здобуття наук. ступеня канд. філол. наук: спец. 10.02.01 “Українська мова". Дніпропетровськ, 2005. $19 \mathrm{c}$.

13.Кобченко Н. Реалізація адресатності в синтаксемах синкретичної семантики. Лінгвістичні студії. Вип. 22. Донецьк: ДонНУ, 2011. С. 168-173.

14.Кобченко Н. Тяжіння: проблема дефініції // Науковий вісник Херсон. держ. ун-ту. Сер. “Лінгвістика”. Вип. 25. Херсон, 2016. C. 9-15.

15.Колесникова Т.В. О понятии синкретизма в языкознании / URL: http://mx.pglu.ru/lib/publications/University_Reading/2008/IV/ uch_2008_IV_00025.pdf

16.Кононенко В.І. Подвійні синтаксичні зв'язки // Укр. мова i літ. в шк. 1975. № 11. С. 31-42.

17.Кононенко B.I. Омоніміка синтаксичних конструкцій // В.І. Кононенко. Мова. Культура. Стиль: [зб. статей]. К. - ІваноФранківськ: Плай, 2002. С. 118-126.

18. Межов О.Г. Типологія мінімальних семантико-синтаксичних одиниць: [монографія]. Луцьк: Волин. нац. ун-т ім. Лесі Українки, 2012. 464 c.

19. Мигирин В.Н. Очерки по теории процессов переходности в русском языке. Бельцы, 1971. 199 с.

20.Наливайко Ю.Ю. Синкретизм у системі членів речення: автореф. дис. на здобуття канд. філол. наук: 10.02.01 "Українська мова”. Дніпропетровськ, 2007. 20 с.

21.Норман Б.Ю. К вопросу о двусторонней синтаксической связи // Рус. яз. в шк. 1980. № 4. С. 84-87. 
22.Ожоган В. Синтаксис складнопідрядного елементарного речення. Кіровоград: ЛОВ, 2006. 123 с.

23.Павлюковец М.А. К вопросу о синкретизме в лингвистической теории // Известия Рос. гос. пед. ун-та им. А.И. Герцена. 2008. № 74 (1). С. 383-390.

24. Пастухова Л.С. Расположение в предложении членов с двойной синтаксической связью // Проблемы теории членов предложения. Кишинев, 1973. С. 5-80.

25. Селіванова O. Сучасна лінгвістика: термінологічна енциклопедія. Полтава: Довкілля-К, 2006. 716 с.

26. Теория функциональной грамматики: введение, аспектуальность, временная локализованность, таксис / отв. ред. А.В. Бондарко. 3-е изд., стереот. М.: УРСС, 2003. 352 с.

27. Українська мова: Енциклопедія. К.: Вид-во "Укр. енцикл." ім. М.П. Бажана, 2004. 824 с.

28. Федосов В.А. Основные понятия русского традиционного синтаксиса в отношении к лексическому составу предложения // Studia Slavica Academiae Scientiarum Hungaricae. 2006. Vol. 51, iss. 34. Pp. 387-409. DOI: 10.1556/SSlav.51.2006.3-4.13

29. Христіанінова Р.О. Складнопідрядні речення в сучасній українській літературній мові: [монографія]. К.: Інститут української мови; Видавничий дім Дмитра Бураго, 2012. 368 с.

30. Христіанінова Р.О. Внутрішній синкретизм складнопідрядних речень. Наук. записки Бердянського держ. пед. У-ту. Сер.: Філологічні науки. 2014. Вип. 1. С. 209-219.

31. Чеснокова Л.Д. Связи слов в современном русском языке: [пособие для учителей]. М.: Просвещение, 1980. 110 с.

32. Шведова Н.Ю. Согласование и координация: их сходство и различия // Проблемы истории и диалектологии славянских языков: [сб. ст. к 70-летию члена-корреспондента АН СССР В.И. Борковского]. М.: Наука, 1971. С. 312-319.

33. Шитик Л.В. Синхронна перехідність синтаксичних одиниць в українській літературній мові: [монографія]. Черкаси: Видавець Чабаненко Ю.А., 2014. 474 с.

34. Aalberse S., Don J. Syncretism in Dutch Dialects // Morphology. 2009. Vol. 19 (1). Pp. 3-14. DOI: 10.1007/s11525-009-9132-y.

35. Baerman M. Directionality and (Un)Natural Classes in Syncretism // Language. 2004. Vol. 80 (4). Pp. 807-827. DOI: 10.1353/lan.2004.0163 
36.Baerman M., Brown D., Corbett G. The Syntax-Morphology Interface: a Study of Syncretism. Cambridge: Cambridge University Press, 2005. 279 pp.

37. Bank S. Segmentation: a Remark on the Syncretism Principle // Morphology. 2017. Vol. 27 (1). Pp. 1-20. DOI: 10.1007/s11525-0169295-2

38. Brown D., Tiberius C., Corbett G. Inflectional syncretism and corpora // Paper presented at the 5th International Workshop on Linguistically Interpreted Corpora (LINC-04) held at the 20th International Conference on Computational Linguistics, Geneva, 2004. URL: http://epubs.surrey.ac.uk/1059/

39. Feldstein R. F. Russian Stress and the Notion of Syncretism // Balto-slavjanskaja akcentologija. IWoBA VII: (Balto-Slavic Accentology. IWoBA VII) Moscow, 2016. URL: http://inslav.ru/images/stories/pdf/2016_IWoBA.pdf

40.Hein J., Murphy A. Case Mismatches and Syncretism in ATB Dependencies // Replicative Processes in Grammar (Linguistische Arbeits Berichte). Leipzig: University of Leipzig, 2016. Pp. 301-350.

41.Jászay L. K характеристике вида и проблеме его определения. Studia Slavica Academiae Scientiarum Hungaricae. 2003. 48. 1-3. Pp. 123-133. URL: http://dx.doi.org/10.1556/SSlav.48.2003.1-3.10

42. Meiser G. Syncretism in Indo-European Languages - Motives, Process and Results // Transactions of the philological society. 1992. Vol. 90, iss. 2. Pp. 187-218.

43. Sauerland U., Bobaljik J. D. Syncretism Distribution Modelling: Accidental Homophony as A Random Event // Proceedings of GLOW in Asia IX 2012. Tsu, Japan, 2013: University of Mie. Pp. 31-53. URL: http://ling.auf.net/lingbuzz/001718

\section{Information about the author:} Kobchenko N. V.,

Doctor in Philology, Associate Professor (Docent), Associate Professor at the Ukrainian Language Department, National University of Kyiv-Mohyla Academy 2, Skovorody str., Kyiv, 04070, Ukraine 